\title{
PENERAPAN MEDIA GAMBAR UNTUK MENINGKATKAN HASIL BELAJAR KOSA KATA BAHASA ARAB (MUFRODAT) PADA SISWA KELAS II A MADRASAH IBTIDAIYAH RAUDHATUL ULUM SAKATIGA INDRALAYA OGAN ILIR
}

\author{
Komputri Apria Santi \\ Sekolah Tinggi Ilmu Tarbiyah Raudhatul Ulum Sakatiga \\ Email:komputri@stit-ru.ac.id
}

\begin{abstract}
Abstrak
This journal is entitled: The Application of Image Media to Improve Learning Results of Arabic Vocabulary (Mufrodat) in Class II A Madrasa Ibtidaiyah Raudhatul Ulum Sakatiga Indralaya Ogan Ilir. Image media is one of the easiest types of media to apply. Images basically can help students in learning and can arouse their interest in learning. The media which is applied by teachers in learning activities of Arabic vocabulary is less varied and can cause low students in remembering Arabic vocabulary. Then the value of learning outcomes has a considerable influence in motivating students. In order to improve student learning outcomes, the ideal teacher must try to use a variety of strategies, including by using effective and pleasing learning media. The use of appropriate learning media will make students more active, enthusiastic, and make it easier for students to digest the lessons given by their teacher during the learning process. The type of research used is qualitative research. While the data analysis technique uses descriptive qualitative method that describes the data collected in the form of words instead of numbers. Data collection is done by pre-test and post-test techniques, observations, interviews, documentation. Then the data sources used are primary data and secondary data. The objects in this study were Arabic language teachers, and 22 students as respondents. After conducting the process of data collection and data analysis, it was concluded that, the application of image media regarding Arabic mufrodat in class II A MI Raudhatul Ulum Sakatiga is good $75.75 \%$. So it can be said that the application of image media regarding Arabic mufrodat is in the good category that is $75.75 \%$. Based on the results of the use of the " $t$ " Test, it can be conclusively said that the Application of Image Media to Improve the Learning Results of Arabic Vocabulary (mufrodat) on Students Class II A MI Raudhatul Ulum, has shown its real effectiveness. This can be proven because to is greater than ttitu: $2.09<5.11>2.83$.
\end{abstract}

Kata Kunci: Image Media, Arabic Vocabulary

\section{Pendahuluan}

Tingkat keefektifan pembelajaran di sekolah salah satunya ditentukan dan dipengaruhi oleh kemampuan guru menerapkan dan mengelola proses pembelajaran. Guru harus mampu menyajikan apa yang diajarkan secara nyata agar mudah dipahami oleh siswanya. Dengan tingkat perkembangan usia siswa yang selalu bertambah dan tumbuh berkembang maka dibutuhkan media pembelajaran yang tepat. 


\section{Penerapan Media Gambar Untuk Meningkatkan Hasil Belajar Kosakata Bahasa}

Arab (Mufrodat) Pada Siswa Kelas II A Madrasah Ibtidaiyah Raudhatul Ulum Sakatiga Indralaya Ogan Ilir

\section{Komputri Apria Santi}

Dalam keseluruhan pendidikan di sekolah kegiatan belajar merupakan kegiatan yang paling pokok ini berarti bahwa berhasil tidaknya pencapaian tujuan pendidikan banyak bergantung kepada bagaimana proses belajar yang dialami oleh siswa sebagai anak didik (Daryanto, 2010: 1). Salah satu indikator pendidikan berkualitas adalah keberhasilan hasil belajar siswa. Nilai hasil belajar siswa dapat ditingkatkan apabila pembelajaran berlangsung secara efektif dan efisien, dengan ditunjang oleh tersedianya sarana dan prasarana pendukung serta kecakapan guru dalam pengelolaan kelas dan penguasaan materi yang memadai. Pada umumnya setiap guru mengharapkan keberhasilan siswanya dalam menerima pelajaran yang diharapkan.

Strategi yang digunakan bersifat menoton. Media yang di terapkan oleh guru kurang bervariasidapat menyebabkan rendahnya siswa dalam mengingat kosa kata bahasa Arab. Maka Nilai hasil belajar memiliki pengaruh yang cukup besar dalam memotivasi peserta didik. Demi meningkatkan hasil belajar peserta didiknya guru yang ideal senantiasa berupaya dengan berbagai strategi, termasuk diantaranya ialah dengan menggunakan media belajar yang efektif dan menyenangkan hati. Penggunaan media belajar yang tepat akan membuat peserta didik lebih aktif, semangat, dan lebih mempermudah mereka dalam mencerna pelajaran yang diberikan gurunya selama proses pembelajaran.

Media gambar merupakan salah satu jenis media yang paling mudah diterapkan. Gambar pada dasarnya membantu mendorong para siswa dan dapat meningkatkan minatnya pada pelajaran. Selain sederhana dan mudah pembuatannya media gambar juga termasuk media yang relatif murah ditinjau dari segi biayanya. Gambar juga dapat mengatasi batasan ruang dan waktu. Tidak semua benda, objek atau peristiwa dapat dibawa ke kelas, dan tidak selalu bisa anak-anak dibawa ke objek/peristiwa tersebut.

Gambar atau foto dapat mengatasi hal tersebut. Jadi media gambar adalah media yang dipergunakan untuk menyalurkan pesan dari sumber ke penerima (siswa). Media gambar dalam pembelajaran adalah untuk membangkitkan motivasi belajar siswa dan sebagai alat komunikasi dalam menyampaikan pesan (materi pembelajaran) yang lebih konkrit pada siswa, sehingga lebih mudah dipahami (Angkowo dan Kosasi, 2010: 28). Media gambar juga bermanfaat untuk menkonkretkan hal-hal yang belum jelas menjadi nyata. Setiap metode dan media yang digunakan oleh guru dalam kegiatan pembelajaran, pastinya mempunyai beberapa kelebihan.

Adapun kelebihan-kelebihan dalam penggunaan media gambar ialah (Sadiman, dkk: 2009: 29-31):

1. Sifatnya kongkrit. Gambar/foto lebih realistis menunjukkan pokok masalah dibandingkan dengan media verbal biasa.

2. Gambar dapat mengatasi batasan ruang dan waktu. Tidak semua benda, objek atau peristiwa dapat dibawa ke kelas, dan tidak selalu bisa anak-anak dibawa ke objek/peristiwa tersebut.

3. Media gambar/foto dapat mengatasi keterbatasan pengamatan kita. 
4. Foto dapat memperjelas suatu masalah, dalam bidang apa saja dan untuk tingkat usia berapah, sehingga dapat mencegah atau membetulkan kesalahpahaman.

5. Foto harganya murah dan gampang didapat serta digunakan, tanpa memerlukan peralatan khusus.

Namun perlu diingat, bahwa peranan media tidak akan terlihat bila penggunaanya tidak sejalan dengan isi dari tujuan pengajaran yang telah dirumuskan. Karena itu, tujuan pengajaran harus dijadikan sebagai pangkal acuan untuk menggunakan media. Apabila diabaikan, maka media bukan lagi sebagai alat bantu pengajaran, tetapi sebagai penghambat dalam pencapaian tujuan secara efektif dan efisien.

Pesan yang akan disampaikan dituangkan ke dalam komunikasi visual, di samping itu media gambar berfungsi pula untuk menarik perhatian, memperjelas sajian, dan mempermudah peserta didik dalam mengingat pelajaran. Gambar adalah media yang paling umum dipakai. Dia merupakan bahasa yang umum, yang dapat dimengerti dan dinikmati di mana-mana. Oleh karena itu, pepatah Cina yang mengatakan bahwa sebuah gambar berbicara lebih banyak dari pada seribu kata (Sadiman, dkk, 2009: 29-30).

\section{Metode Penelitian}

Dalam penulisan jurnal ini akan menggunakan metode penelitian sebagai berikut:

1. Jenis penelitian

Jenis penelitian ini adalah kualitatif yang bersifat dekskriftif, meliputi tentang penerapan media gambar untuk meningkatkan hasil belajar kosa kata bahasa Arab (Mufrodat) pada siswa kelas II A MI Raudhatul Ulum Sakatiga Ogan Ilir.

2. Metode Pengumpulan Data

a. Tekhnik Pre-test dan Pos-test

Tekhnik ini digunakan dengan memberikan tes kepada siswa pada saat sebelum tindakan penerapan media gambar dan setelah tindakan penerapan media gambar untuk mengetahui hasil belajar siswa, demi mengetahui keefektifan media ini bagi prestasi belajar siswa.

b. Metode Observasi

Dalam penelitian ini penulis akan turun langsung ke lokasi penelitian untuk mengumpulkan data yang diperlukan.

c. Metode Wawancara

Dalam metode ini peneliti mengadakan wawancara dengan guru-guru, guru wali kelas dan guru bahasa Arab MIRU Sakatiga Indralaya Ogan Ilir untuk melengkapi data yang penulis butuhkan yaitu metode yang di gunakan guru dalam mengajar bahasa Arab dan tentang sejarah berdirinya MIRU Sakatiga Indralaya Ogan Ilir, visi dan misi MIRU Sakatiga Indralaya Ogan Ilir.

d. Metode Dokumentasi 
Penerapan Media Gambar Untuk Meningkatkan Hasil Belajar Kosakata Bahasa Arab (Mufrodat) Pada Siswa Kelas II A Madrasah Ibtidaiyah Raudhatul Ulum Sakatiga Indralaya Ogan Ilir

\section{Komputri Apria Santi}

Metode dokumentasi yang dilakukan peneliti yaitu teknik pengumpulan data yang ditujukan untuk mencari data tertulis tentang identitas MIRU Sakatiga Indralaya, jumlah tenaga pengajar dan pegawai, struktur organisasi, dan, nilai pelajaran.

e. Populasi dan sampel

1) Populasi

Populasi adalah keseluruhan subjek penelitian (Arikunto, 2010: 173). Sedangkan menurut Sutrisno Hadi, populasi adalah seluruh jumlah subjek yang dikenai penyelidikan, yang demikian tidak mempunyai sifat yang sama (Hadi, 1985: 21). Apabila seseorang ingin meneliti semua elemen yang ada dalam wilayah penelitian, maka peneltitiannya merupakan penelitian populasi. Studi atau penelititaannya juga disebut studi populasi atau studi sensus.

Dalam penelitian ini yang dijadikan populasi adalah seluruh siswa dan siswi kelas II A MI Raudatul Ulum Sakatiga yang berjumlah 22 siswa, 14 siswa laki-laki dan 8 siswa perempuan.

2) Sampel

Bila populasi besar dan peneliti tidak mungkin mempelajari semua yang ada pada populasi, maka peneliti dapat mengunakan sampel yang diambil dari populasi itu. Untuk itu sampel yang diambil dari populasi harus benar-benar refresentative (mewakili) (Sugiono, 2009: 62).

Dalam hal ini peneliti mengambil sampel terhadap siswa dan siswi di kelas II A MI Raudhatul Ulum Sakatiga yang berjumlah 22 orang siswa, 14 siswa putra dan 8 siwa putri. Adapun sampel yang diambil dari populasi adalah seluruh siswa dan siswi kelas II A MI Raudhatul Ulum Sakatiga.

3) Teknik Analisis Data Penelitian

Terlebih dahulu data yang terkumpul diolah klasifikasi data, kemudian dianalisa dengan dengan rumus sebagai berikut:

$$
\text { to }=\frac{\mathrm{MD}}{\mathrm{SE}_{\mathrm{MD}}}
$$

$\mathrm{MD}=$ Mean of DifferenceNilai Rata-rata Hitung dari Beda/Selisih antara Skor Variabel I dan Skor Variabel II, yang dapat diperoleh dengan rumus :

$$
\mathrm{MD}_{\mathrm{D}}=\frac{\sum_{\mathrm{D}}}{\mathrm{SE}_{\mathrm{MD}}}
$$

$\sum \mathrm{D}=$ Jumlah Beda/Selisih antara Skor Variabel I dan Skor Variabel II, dan D dapat diperoleh dengan rumus :

$$
\begin{gathered}
\mathrm{D}=\mathrm{X}-\mathrm{Y} \\
\mathrm{N}=\text { Number of } \text { Cases }=\text { Jumlah Subjek yang kita teliti }
\end{gathered}
$$

SEMD = Standar error(Standar kesesatan) dari Mean of Difference yang dapat diperoleh dengan rumus :

$$
S E M D=\frac{S_{D}}{\sqrt{\mathrm{N}-1}}
$$

$\mathrm{SD}_{\mathrm{D}}=$ Deviasi Standar dari perbedaan antara skor Variabel I dan Skor Variabel II, yang dapat diperoleh dengan rumus : 


$$
\begin{aligned}
& \mathrm{SDD}=\sqrt{\frac{\sum \mathrm{D}^{2}}{\mathrm{~N}}-\left(\frac{\sum \mathrm{D}}{\mathrm{N}}\right)^{2}} \\
& \mathrm{~N}=\text { Number of Cases (Sudijono, 2010: 305-306) }
\end{aligned}
$$

\section{Hasil Penelitian}

1. Analisis hasil belajar siswa

Sebelum peneliti melakukan tindakan kelas peneliti melakukan wawancara dahulu kepada guru bahasa Arab Madrasah Ibtidaiyah Raudhatul Ulum Sakatiga. Salah satu tujuan peneliti melakukan wawancara dengan guru bahasa Arab ialah untuk mengetahui apakah media gambar telah digunakan oleh guru bahasa Arabuntuk meningkatkan meningkatkan hasil belajar kosa kata bahasa Arab (mufrodat) pada siswa kelas II A Madrasah Ibtidaiyah Raudhatul Ulum Sakatiga.

Sebagaimana hasil wawancara dengan guru bahasa Arab Madrasah Ibtidaiyah Raudhatul Ulum Sakatiga pada tanggal 27-10-2012 beliau menerapkan:“Selama saya menagajar di MI Rudhatul Ulum ini saya belum pernah menerapkan media gambar pada kegiatan belajar mengajar dipelajaran Bahasa $\mathrm{Arab}^{\prime 1}$

Dari wawancara di atas dapat disimpulakan bahwa media gambar belum pernah digunakan oleh guru bahasa Arab untuk memberikan materi terhadap siswa kelas II A Madrasah Ibtidaiyah Raudhatul Ulum.

Setelah peneliti telah mengetahui bahwa media gambarbelum digunakan guru bahasa Arab, maka peneliti langsung terjun ke lapangan atau penelitian tindakan kelas.Untuk mengetahui hasil belajar siswa, maka penulis mencoba menganalisis hasil belajar siswa melalui Pre-test dan Pos-test. Adapun di bawah ini penulis akan sajikan hasil Pre-test dan hasil Pos-test :

\section{Hasil Pre Test}

\begin{tabular}{|c|l|c|c|l|}
\hline No & \multicolumn{1}{|c|}{ Nama } & Pre-test & SKM & Keterangan \\
\hline 1 & $\begin{array}{l}\text { Amelia Adibah } \\
\text { Khairunnisa }\end{array}$ & 50 & 60 & Belum Tuntas \\
\hline 2 & Bimo Rizmandhoni APM & 50 & 60 & Belum Tuntas \\
\hline 3 & Faiza Nabilah & 70 & 60 & Tuntas \\
\hline 4 & Islami Aiman Yaqin॰ & 60 & 60 & Tuntas \\
\hline 5 & Kharitsa Rahmaniyah & 80 & 60 & Tuntas \\
\hline 6 & Londa Nur Jannah & 40 & 60 & Belum Tuntas \\
\hline 7 & M. Abid Al- Ikhsan & 100 & 60 & Tuntas \\
\hline 8 & M. Fadil & 20 & 60 & Belum Tuntas \\
\hline 9 & $\begin{array}{l}\text { M. Mirzan Akbar } \\
\text { Athoillah }\end{array}$ & 90 & 60 & Tuntas \\
\hline 10 & M. Naufal Abdallah & 70 & 60 & Tuntas \\
\hline 11 & M. Rivaldo & 70 & 60 & Tuntas \\
\hline
\end{tabular}

1Parasih, S.Pd.I, guru Bahasa Arab Madrasah Ibtidaiyah Raudhatul Ulum Sakatiga, wawancara langsung pada hari ssabtu tanggal 27-10-2012, pukul 10. 15 WIB 
Penerapan Media Gambar Untuk Meningkatkan Hasil Belajar Kosakata Bahasa Arab (Mufrodat) Pada Siswa Kelas II A Madrasah Ibtidaiyah Raudhatul Ulum Sakatiga Indralaya Ogan Ilir

Komputri Apria Santi

\begin{tabular}{|c|l|c|c|l|}
\hline 12 & M. Rizky Al-Qhifari & 90 & 60 & Tuntas \\
\hline 13 & M. Said & 60 & 60 & Tuntas \\
\hline 14 & M. Taqyuddin & 100 & 60 & Tuntas \\
\hline 15 & M. Thoriq Akbar & 90 & 60 & Tuntas \\
\hline 16 & Masely Azzahrah & 100 & 60 & Tuntas \\
\hline 17 & M. Tabris Naufal & 10 & 60 & Belum Tuntas \\
\hline 18 & Muslih & 30 & 60 & Belum Tuntas \\
\hline 19 & Putri Asyifah Fahlevi & 10 & 60 & Belum Tuntas \\
\hline 20 & Riza Pratama Sya'ban & 60 & 60 & Tuntas \\
\hline 21 & Risky Nailah & 100 & 60 & Tuntas \\
\hline 22 & Rahma Aliyah & 100 & 60 & Tuntas \\
\hline \multicolumn{2}{|c|}{ Jumlah } & $\mathbf{1 . 4 5 0}$ & & \\
\hline \multicolumn{2}{|c|}{ Rata-rata } & $\mathbf{6 5 , 9 0}$ & & \\
\hline
\end{tabular}

Dari tabel diatas dapat diketahui bahwa nilai rata-rata Pra Tindakan siswa adalah berdasarkan SKM (Standar Ketuntasan Minimum) dari MIRU Sakatiga Indralaya yaitu 60 Sedangkan rata-rata nilai siswa sudah mencapai SKM, Juga dapat dilihat pada tabel masih banyak siswa yang belum mencapai standar ketuntasan yaitu 7 orang. Di sini penulis mengharapkan dengan adanya penerapan media gambar dalam meningkatkan prestasi belajar siswa, dapat meningkatkan lagi hasil belajarnya.

Hasil Post Test
\begin{tabular}{|c|l|c|c|c|}
\hline NO & \multicolumn{1}{|c}{ NAMA } & POS-TEST & SKM & Keterangan \\
\hline 1 & $\begin{array}{l}\text { Amelia Adibah } \\
\text { Khairunnisa }\end{array}$ & 70 & 60 & Tuntas \\
\hline 2 & Bimo Rizmandhoni APM & 80 & 60 & Tuntas \\
\hline 3 & Faiza Nabilah & 100 & 60 & Tuntas \\
\hline 4 & Islami Aiman Yaqin॰ & 90 & 60 & Tuntas \\
\hline 5 & Kharitsa Rahmaniyah & 90 & 60 & Tuntas \\
\hline 6 & Londa Nur Jannah & 100 & 60 & Tuntas \\
\hline 7 & M. Abid Al- Ikhsan & 100 & 60 & Tuntas \\
\hline 8 & M. Fadil & 70 & 60 & Tuntas \\
\hline 9 & $\begin{array}{l}\text { M. Mirzan Akbar } \\
\text { Athoillah }\end{array}$ & 100 & 60 & Tuntas \\
\hline 10 & M. Naufal Abdallah & 80 & 60 & Tuntas \\
\hline 11 & M. Rivaldo & 90 & 60 & Tuntas \\
\hline 12 & M. Rizky Al-Qhifari & 100 & 60 & Tuntas \\
\hline 13 & M. Said & 90 & 60 & Tuntas \\
\hline 14 & M. Taqyuddin & 100 & 60 & Tuntas \\
\hline 15 & M. Thoriq Akbar & 100 & 60 & Tuntas \\
\hline
\end{tabular}


RAUDHAH Proud To Be Professionals Jurnal Tarbiyah)damiyah

Volume 4 Nomor 2 Edisi Desember 2019

P-ISSN : 2541-3686

\begin{tabular}{|c|l|c|c|c|}
\hline 16 & Masely Azzahra & 100 & 60 & Tuntas \\
\hline 17 & M. Tabris Naufal & 80 & 60 & Tuntas \\
\hline 18 & Muslih & 80 & 60 & Tuntas \\
\hline 19 & Putri Asyifah Fahlevi & 60 & 60 & Tuntas \\
\hline 20 & Riza Pratama Sya'ban & 80 & 60 & Tuntas \\
\hline 21 & Risky Nailah & 100 & 60 & Tuntas \\
\hline 22 & Rahma Aliyah & 100 & 60 & Tuntas \\
\hline \multicolumn{2}{|c|}{ Jumlah } & $\mathbf{1 . 9 6 0}$ & & \\
\hline Rata-rata & $\mathbf{8 9 , 0 9}$ & & \\
\hline
\end{tabular}

Dari tabel di atas dapat dilihat bahwa nilai rata-rata murid adalah 89,09, dimana berdasarkan SKM (Standar Ketuntasan Minimum) dari MIRU Sakatiga Indralaya adalah 60. Dapat terlihat bahwa tindakan pada Penerapan media Gambar, maka dapat dilihat bahwa hasil atau nilai siswa meningkat dan mencapai SKM, dan tidak ada lagi siswa yang tidak mencapai SKM.

\section{Analisis Pre-Test dan Post-TestNilai Bahasa Arab}

a. Sebelum Penerapan Media Gambar (Pre-Test)

Untuk mengetahui hasil belajar siswa sebelum diterapkannya media gambar, maka penulis mencoba menganalisis hasil belajar siswa melalui Pre-Test dan PostTest, adapun nilai Pre-Test yang peneliti peroleh sebagai berikut :

Hasil Pre Test

\begin{tabular}{|c|l|c|c|l|}
\hline No & \multicolumn{1}{|c|}{ Nama } & Pre-test & SKM & Keterangan \\
\hline 1 & Amelia Adibah Khairunnisa & 50 & 60 & Belum Tuntas \\
\hline 2 & Bimo Rizmandhoni APM & 50 & 60 & Belum Tuntas \\
\hline 3 & Faiza Nabilah & 70 & 60 & Tuntas \\
\hline 4 & Islami Aiman Yaqino & 60 & 60 & Tuntas \\
\hline 5 & Kharitsa Rahmaniyah & 80 & 60 & Tuntas \\
\hline 6 & Londa Nur Jannah & 40 & 60 & Belum Tuntas \\
\hline 7 & M. Abid Al- Ikhsan & 100 & 60 & Tuntas \\
\hline 8 & M. Fadil & 20 & 60 & Belum Tuntas \\
\hline 9 & M. Mirzan Akbar Athoillah & 90 & 60 & Tuntas \\
\hline 10 & M. Naufal Abdallah & 70 & 60 & Tuntas \\
\hline 11 & M. Rivaldo & 70 & 60 & Tuntas \\
\hline 12 & M. Rizky Al-Qhifari & 90 & 60 & Tuntas \\
\hline 13 & M. Said & 60 & 60 & Tuntas \\
\hline 14 & M. Taqyuddin & 100 & 60 & Tuntas \\
\hline 15 & M. Thoriq Akbar & 90 & 60 & Tuntas \\
\hline 16 & Masely Azzahrah & 100 & 60 & Tuntas \\
\hline 17 & M. Tabris Naufal & 10 & 60 & Belum Tuntas \\
\hline 18 & Muslih & 10 & 60 & Belum Tuntas \\
\hline 19 & Putri Asyifah Fahlevi & & & \\
\hline
\end{tabular}


Penerapan Media Gambar Untuk Meningkatkan Hasil Belajar Kosakata Bahasa Arab (Mufrodat) Pada Siswa Kelas II A Madrasah Ibtidaiyah Raudhatul Ulum Sakatiga Indralaya Ogan Ilir

Komputri Apria Santi

\begin{tabular}{|c|l|c|c|l|}
\hline 20 & Riza Pratama Sya'ban & 60 & 60 & Tuntas \\
\hline 21 & Risky Nailah & 100 & 60 & Tuntas \\
\hline 22 & Rahma Aliyah & 100 & 60 & Tuntas \\
\hline \multicolumn{2}{|c|}{ Jumlah } & $\mathbf{1 . 4 5 0}$ & & \\
\hline \multicolumn{2}{|c|}{ Rata-rata } & $\mathbf{6 5 , 9 0}$ & & \\
\hline
\end{tabular}

Dari tabel di atas dapat diketahui nilai-nilai siswa sebelum diterapkannya media gambar, kemudian hasil atau nilai dari responden tersebut selanjutnya direkapitulasi dan dianalisis dengan mengunakan statistik sebagai berikut :

Variabel X

$50,50,70,60,80,40,100,20,90,70$

$70,90,60,100,90,100,10,30,10,60$

100,100 .

Distribusi Frekuensi Nilai Pre-Test Siswa

\begin{tabular}{|c|c||c|c|c|c||}
\hline $\mathrm{X}$ & $\mathrm{F}$ & $\mathrm{fX}$ & $\mathrm{X}$ & $\mathrm{X}^{2}$ & $\mathrm{Fx}^{2}$ \\
\hline \hline 100 & 5 & 500 & 34,1 & $1.162,81$ & $5.814,05$ \\
90 & 3 & 270 & 24,1 & 580,81 & $1.742,43$ \\
80 & 1 & 80 & 14,1 & 198,81 & 198,81 \\
70 & 3 & 210 & 4,1 & 16,81 & 50,43 \\
60 & 3 & 180 & $-5,9$ & 34,81 & 104,43 \\
50 & 2 & 100 & $-15,9$ & 252,81 & 505,62 \\
40 & 1 & 40 & $-25,9$ & 670,81 & 670,81 \\
30 & 1 & 30 & $-35,9$ & $1.288,81$ & $1.288,81$ \\
20 & 1 & 20 & $-45,9$ & $2.106,81$ & $2.106,81$ \\
10 & 2 & 20 & $-55,9$ & $3.124,81$ & $6.249,62$ \\
\hline Total & $\mathrm{N}=22$ & $\sum \mathrm{x}^{2}=1.040$ & $\sum \mathrm{x}=-109$ & $\sum \mathrm{x}^{2}=9438,1$ & $\sum \mathrm{fx}^{2}=18731,82$ \\
\hline
\end{tabular}

1) Mencari Mean-nya dengan rumus (Sudijono, 2010: 159) :

$$
\begin{aligned}
& M_{x}=\frac{\sum f Y}{N} \\
& M_{x}=\frac{1450}{22} \\
& M_{x}=65,90
\end{aligned}
$$

Keterangan :

$\mathrm{Mx}=$ Nilai rata-rata dari variable $\mathrm{x}$

$\sum \mathrm{fx}=$ Jumlah hasil perkalian antara deviasi tiap-tiap interval $(X)$ dengan frekuensi masing-masing interval yang bersangkutan.

$\mathrm{N} \quad=$ Number of Cases

2) Mencari deviasi $x$ dengan rumus (Sudijono, 2010: 158) $: x=X-M_{x}$

$$
\begin{aligned}
& x=X-M_{x} \\
& x=100-65,90 \\
& x=34,1
\end{aligned}
$$

Keterangan : 
RAUDHAH Proud To Be Professionals gurnal Tarbiyakndlamiyak

Volume 4 Nomor 2 Edisi Desember 2019

P-ISSN : 2541-3686

$\mathrm{x}=$ Hasil dari pengurangan deviasi tiap-tiap interval $(X)$ dengan nilai ratarata dari masing-masing variable $x$

$\mathrm{X}=$ Variabel $\mathrm{x}$

$\mathrm{M}_{\mathrm{x}}=$ Nilai rata-rata dari variable $\mathrm{x}$

3) Menguadratkan $x$ sehingga diperoleh $x^{2}$, setelah itu di jumlahkan, sehingga diperoleh $\sum \mathrm{x}^{2}=9438,1$

4) Memperkalikan frekuensi dengan $x^{2}$, sehingga di peroleh $\sum f x^{2}$, setelah itu dijumlahkan, di peroleh $\sum \mathrm{fx}^{2}=18731,81$

5) Mencari SD-nya dengan rumus (Sudijono, 2010: 160):

$$
\begin{aligned}
& \mathrm{SD}_{\mathrm{x}}=\sqrt{\frac{\sum \mathrm{fx}^{2}}{\mathrm{~N}}} \\
& \mathrm{SD}_{\mathrm{x}}=\sqrt{\frac{18731,82}{22}} \\
& \mathrm{SD}_{\mathrm{x}}=\sqrt{851,44} \\
& \mathrm{SD}_{\mathrm{x}}=29,17
\end{aligned}
$$

Keterangan :

$\mathrm{SD}_{\mathrm{x}}=$ Deviasi standar $\mathrm{x}$

$\sum \mathrm{fx}^{2}=$ Jumlah hasil perkalian antara frekuensi masing-masing sekor, dengan deviasi sekor yang telah dikuadratkan.

$\mathrm{N}=$ Number of Cases

Setelah di ketahui mean skor dan standar deviasi skor tentang nilai Pre-Test Siswa Kelas II A MI Raudhatul Ulum Ogan Ilir maka selanjutnya adalah menetapkan kategori TSR dengan menggunakan patokan sebagai berikut Sudijono, 2010: 176) :

$\begin{array}{cc}\mathrm{M}+1 \mathrm{SD} & \begin{array}{l}\text { Rangking Ataas } \\ \text { Rangking Tengah }\end{array} \\ \mathrm{M}-1 \mathrm{SD} & \text { Rangking Bawah }\end{array}$

Adapun kategori tersebut adalah :

$\begin{array}{ll}\longrightarrow & \mathrm{M} \\ \stackrel{\mathrm{M}-1 \mathrm{SD}=65,9-29,17=36,73=37}{\longrightarrow} & \mathrm{S}\end{array}$

Penjelasan :

a) Nilai 95 ke atas adalah tinggi, berarti nilai Pre-Test siswa kelas II A MI Raudhatul Ulum tergolong tinggi.

b) Nilai antara 40 dan 95 adalah sedang, berarti nilai Pre-Test siswa kelas II A MI Raudhatul Ulum tergolong sedang. 
Penerapan Media Gambar Untuk Meningkatkan Hasil Belajar Kosakata Bahasa Arab (Mufrodat) Pada Siswa Kelas II A Madrasah Ibtidaiyah Raudhatul Ulum Sakatiga Indralaya Ogan Ilir

Komputri Apria Santi

c) Nilai 40 ke bawah adalah rendah, berarti nilai Pre-Test siswa kelas II A MI Raudhatul Ulum tergolong rendah.

Distribusi Frekuensi dan Persentase TSR Nilai Pre-Test Siswa Kelas II A MI Raudhatul Ulum

\begin{tabular}{|c|c|c|}
\hline $\begin{array}{c}\text { Nilai Pre-Test } \\
\text { Siswa }\end{array}$ & Frekuensi & Persentase \\
\hline \hline Tinggi & 5 & $22,73 \%$ \\
Sedang & 12 & $54,54 \%$ \\
Rendah & 5 & $22,73 \%$ \\
\hline Jumlah & 22 & $100 \%$ \\
\hline
\end{tabular}

Mengacu pada tabel di atas dapat dipahami, bahwa hasil Pre-Test Pada Siswa Kelas II A MI Raudhatul Ulum adalah dalam kategori sedang, yaitu 12 orang responden (54,54\%). Responden yang mendapatkan nilai tinggi adalah 5 orang responden $(22,73 \%)$ dan mendapatkan nilai rendah 5 orang responden $(22,73 \%)$.

b. Nilai bahasa Arab setelah diterapkannya Media Gambar

Untuk mengetahui keefektifan hasil belajar siswa, maka penulis juga menganalisis hasil belajar siswa melalui Post-Test. Adapun di bawah ini penulis akan sajikan hasil Post-Test :

Hasil Post Test

\begin{tabular}{|c|l|c|c|c|}
\hline NO & \multicolumn{1}{|c|}{ NAMA } & POS-TEST & SKM & Keterangan \\
\hline 1 & Amelia Adibah Khairunnisa & 70 & 60 & Tuntas \\
\hline 2 & Bimo Rizmandhoni APM & 80 & 60 & Tuntas \\
\hline 3 & Faiza Nabilah & 100 & 60 & Tuntas \\
\hline 4 & Islami Aiman Yaqino & 90 & 60 & Tuntas \\
\hline 5 & Kharitsa Rahmaniyah & 90 & 60 & Tuntas \\
\hline 6 & Londa Nur Jannah & 100 & 60 & Tuntas \\
\hline 7 & M. Abid Al- Ikhsan & 100 & 60 & Tuntas \\
\hline 8 & M. Fadil & 70 & 60 & Tuntas \\
\hline 9 & M. Mirzan Akbar Athoillah & 100 & 60 & Tuntas \\
\hline 10 & M. Naufal Abdallah & 80 & 60 & Tuntas \\
\hline 11 & M. Rivaldo & 90 & 60 & Tuntas \\
\hline 12 & M. Rizky Al-Qhifari & 100 & 60 & Tuntas \\
\hline 13 & M. Said & 90 & 60 & Tuntas \\
\hline 14 & M. Taqyuddin & 100 & 60 & Tuntas \\
\hline 15 & M. Thoriq Akbar & 100 & 60 & Tuntas \\
\hline 16 & Masely Azzahra & 100 & 60 & Tuntas \\
\hline 17 & M. Tabris Naufal & 80 & 60 & Tuntas \\
\hline 18 & Muslih & 60 & Tuntas \\
\hline
\end{tabular}


RAUDHAH Proud To Be Professionals gurnal Tarbiyakndlamiyak

Volume 4 Nomor 2 Edisi Desember 2019

P-ISSN : 2541-3686

\begin{tabular}{|l|l|c|c|c|}
\hline 19 & Putri Asyifah Fahlevi & 60 & 60 & Tuntas \\
\hline 20 & Riza Pratama Sya'ban & 80 & 60 & Tuntas \\
\hline 21 & Risky Nailah & 100 & 60 & Tuntas \\
\hline 22 & Rahma Aliyah & 100 & 60 & Tuntas \\
\hline \multicolumn{2}{|c|}{ Jumlah } & $\mathbf{1 . 9 6 0}$ & & \\
\hline \multicolumn{2}{|c|}{ Rata-rata } & $\mathbf{8 9 , 0 9}$ & & \\
\hline
\end{tabular}

Dari tabel di atas dapat diketahui nilai-nilai siswa setelah diterapkannya media gambar, kemudian hasil atau nilai dari responden tersebut selanjutnya direkapitulasi dan dianalisis dengan mengunakan statistik sebagai berikut :

Variabel Y

$70,80,100,90,90,100,100,70,100,80$

$90,100,90,100,100,100,80,80,60,80$

100,100

Distribusi Frekuensi Nilai Post-Test Siswa

\begin{tabular}{|c|c|c|c|c|c|}
\hline $\mathrm{Y}$ & $\mathrm{f}$ & $\mathrm{Fy}$ & $\mathrm{Y}$ & $\mathrm{y}^{2}$ & $\mathrm{Fy}^{2}$ \\
\hline 100 & 10 & 1000 & 10,91 & 119,02 & 1190,2 \\
90 & 4 & 360 & 0,91 & 0,82 & 3,28 \\
80 & 5 & 400 & $-9,09$ & 82,62 & 413,10 \\
70 & 2 & 140 & $-19,09$ & 364,42 & 728,84 \\
60 & 1 & 60 & $-29,09$ & 846,22 & 846,22 \\
\hline \multirow{2}{*}{ Total } & \multirow{2}{*}{$\mathrm{N}=22$} & $\sum \mathrm{y}^{2}$ & $\sum \mathrm{y}=-$ & $\sum \mathrm{y}^{2}=$ & $\sum \mathrm{fx}^{2}=$ \\
& & $=1960$ & 45,45 & $1.413,1$ & $3.181,64$ \\
\hline
\end{tabular}

1) Mencari Mean-nya dengan rumus Sudijono, 2010:158):

$$
\begin{aligned}
& \mathrm{M}_{\mathrm{y}}=\frac{\sum \mathrm{fY}}{\mathrm{N}} \\
& \mathrm{M}_{\mathrm{y}}=\frac{1.960}{22} \\
& \mathrm{M}_{\mathrm{y}}=89,09
\end{aligned}
$$

Keterangan :

$\mathrm{M}_{\mathrm{y}} \quad=$ Nilai rata-rata dari variable y

$\sum \mathrm{f}_{\mathrm{y}}=$ Jumlah hasil perkalian antara deviasi tiap-tiap interval $(\mathrm{Y})$ dengan frekuensi masing-masing interval yang bersangkutan.

$\mathrm{N}=$ Number of Cases

2) Mencari deviasi y dengan rumus (Sudijono, 2010: 159) $: y=Y-M_{x}$

$$
\begin{aligned}
& y=Y-M_{x} \\
& y=100-89,09 \\
& y=10,91
\end{aligned}
$$

$\mathrm{y}=$ Hasil dari pengurangan deviasi tiap-tiap interval $(\mathrm{Y})$ dengan nilai rata-rata dari masing-masing variable y

$\mathrm{Y} \quad=$ Variabel $\mathrm{y}$

$\mathrm{M}_{\mathrm{y}} \quad=$ Nilai rata-rata dari variable $\mathrm{y}$ 
Penerapan Media Gambar Untuk Meningkatkan Hasil Belajar Kosakata Bahasa Arab (Mufrodat) Pada Siswa Kelas II A Madrasah Ibtidaiyah Raudhatul Ulum Sakatiga Indralaya Ogan Ilir

Komputri Apria Santi

3) Menguadratkan y sehingga diperoleh $y^{2,}$ setelah itu di jumlahkan, sehingga diperoleh $\sum \mathrm{y}^{2}=1413,1$

4) Memperkalikan frekuensi dengan $\mathrm{y}^{2}$, sehingga di peroleh $\sum \mathrm{fy}^{2}$, setelah itu dijumlahkan, di peroleh $\sum \mathrm{fy}^{2}=3181,64$

5) Mencari SD-nya dengan rumus (Sudijono, 2010: 165) :

$$
\begin{aligned}
& \mathrm{SD}_{\mathrm{y}}=\sqrt{\frac{\sum \mathrm{fy}^{2}}{\mathrm{~N}}} \\
& \mathrm{SD}_{\mathrm{y}}=\sqrt{\frac{3.181,64}{22}} \\
& \mathrm{SD}_{\mathrm{y}}=\sqrt{144,62} \\
& \mathrm{SD}_{\mathrm{y}}=12,02
\end{aligned}
$$

Keterangan :

$\mathrm{SD}_{\mathrm{y}}=$ Deviasi standar $\mathrm{y}$

$\sum \mathrm{fy}^{2}=$ Jumlah hasil perkalian antara frekuensi masing-masing sekor, dengan deviasi sekor yang telah dikuadratkan.

$\mathrm{N}=$ Number of Cases

Setelah di ketahui mean skor dan standar deviasi skor tentang nilai Post-Test Siswa Kelas II A MI Raudhatul Ulum Ogan Ilir maka selanjutnya adalah menetapkan kategori TSR dengan menggunakan patokan sebagai berikut (Sudijono, 2010: 176) :

$\begin{array}{cc}\longrightarrow \mathrm{M}+1 \mathrm{SD} & \text { Rangking Ataas } \\ \mathrm{M}-1 \mathrm{SD} & \text { Rangking Tengah } \\ & \text { Rangking Bawah }\end{array}$

Adapun kategori tersebut adalah :

$\begin{array}{ll}\longrightarrow \mathrm{M}+1 \mathrm{SD}=89,09+12=100,02=100 & \mathrm{~T} \\ \stackrel{\mathrm{M}-1 \mathrm{SD}=89,09-12=88,97=89}{\longrightarrow} & \mathrm{S} \\ \longrightarrow & \mathrm{R}\end{array}$

Penjelasan :

a) Nilai 100 adalah tinggi, berarti nilai Post-Test siswa kelas II A MI Raudhatul Ulum tergolong tinggi.

b) Nilai antara 80 dan 100 kategori sedang, berarti nilai Post-Test siswa kelas II A MI Raudhatul Ulum tergolong sedang.

c) Nilai 80 ke bawah adalah rendah, berarti nilai Post-Test siswa kelas II A MI Raudhatul Ulum tergolong rendah.

Distribusi Frekuensi dan Persentase TSR Nilai Post-Test Siswa Kelas II A MI Raudhatul Ulum

\begin{tabular}{|l||l|l}
\hline Nilai Post-Test Siswa & Frekuensi & Persentase \\
\hline
\end{tabular}




\begin{tabular}{|c|c|c|}
\hline Tinggi & 10 & $45,45 \%$ \\
Sedang & 4 & $18,19 \%$ \\
Rendah & 8 & $36,36 \%$ \\
\hline Jumlah & 22 & $100 \%$ \\
\hline
\end{tabular}

Mengacu pada tabel di atas dapat dipahami, bahwa hasil Post-Test Pada Siswa Kelas II A MI Raudhatul Ulum adalah dalam kategori tinggi, yaitu 10 orang responden $(45,45 \%)$. Responden yang mendapatkan nilai sedang adalah 4 orang responden $(18,19 \%)$ dan mendapatkan nilai rendah 8 orang responden $(36,36 \%)$.

Jadi, dapat disimpulkan bahwa dengan diterapkannya media gambar hasil belajar siswa meningkat dengan adanya peningkatan hasil belajar antara hasil PreTest dan Hasil Post-Test.

3. Analisis Perbedaan Antara Sebelum dan Sesudah diterapkannya Media Gambar Terhadap Hasil Belajar Siswa.

Perhitungan untuk Memperoleh " $\mathrm{t}$ " dalam Rangka Menguji Kebenaran/Kepalsuan Hipotesis Nihil Tentang Tidak Adanya Perbedaan Nilai yang Signifikan di Kalangan Siswa Kelas II A MI Raudhatul Ulum Antara Sebelum dan Sesudah Diterapkannya Media Gambar (Sudijono, 2010: 310).

\begin{tabular}{|c|c|c|c|c|c|}
\hline \multirow[b]{2}{*}{ NO } & \multirow[b]{2}{*}{ NAMA SISWA } & \multicolumn{2}{|c|}{ NILAI } & \multirow{2}{*}{$\begin{array}{c}D= \\
(X-Y)\end{array}$} & \multirow{2}{*}{$\begin{array}{c}D^{2}= \\
(X-Y)^{2}\end{array}$} \\
\hline & & PRE-TEST(X) & $\begin{array}{c}\text { POST- } \\
\text { TEST(Y) }\end{array}$ & & \\
\hline 1 & Amelia Adibah Khairunnisa & 50 & 70 & -20 & 400 \\
\hline 2 & Bimo Rizmandhoni APM & 50 & 80 & -30 & 900 \\
\hline 3 & Faiza Nabilah & 70 & 100 & -30 & 900 \\
\hline 4 & Islami Aiman Yaqin॰ & 60 & 90 & -30 & 900 \\
\hline 5 & Kharitsa Rahmaniyah & 80 & 90 & -10 & 100 \\
\hline 6 & Londa Nur Jannah & 40 & 100 & -60 & 3.600 \\
\hline 7 & M. Abid Al- Ikhsan & 100 & 100 & 0 & 0 \\
\hline 8 & M. Fadil & 20 & 70 & -50 & 2.500 \\
\hline 9 & M. Mirzan Akbar Athoillah & 90 & 100 & -10 & 100 \\
\hline 10 & M. Naufal Abdallah & 70 & 80 & -10 & 100 \\
\hline 11 & M. Rivaldo & 70 & 90 & -20 & 400 \\
\hline 12 & M. Rizky Al-Qhifari & 90 & 100 & -10 & 100 \\
\hline 13 & M. Said & 60 & 90 & -30 & 900 \\
\hline 14 & M. Taqyuddin & 100 & 100 & 0 & 0 \\
\hline 15 & M. Thoriq Akbar & 90 & 100 & -10 & 100 \\
\hline 16 & Masely Azzahra & 100 & 100 & 0 & 0 \\
\hline 17 & M. Tabris Naufal & 10 & 80 & -70 & 4.900 \\
\hline 18 & Muslih & 30 & 80 & -50 & 2.500 \\
\hline 19 & Putri Asyifah Fahlevi & 10 & 60 & -50 & 2.500 \\
\hline 20 & Riza Pratama Sya'ban & 60 & 80 & -20 & 400 \\
\hline 21 & Risky Nailah & 100 & 100 & 0 & 0 \\
\hline 22 & Rahma Aliyah² & 100 & 100 & 0 & 0 \\
\hline
\end{tabular}

${ }^{2}$ Tanda - (minus) di sini bukanlah tanda aljabar, karena itu hendaknya dibaca: ada selisih/beda skor antara Variabel X dan Variabel Y sebesar 510. 
Penerapan Media Gambar Untuk Meningkatkan Hasil Belajar Kosakata Bahasa Arab (Mufrodat) Pada Siswa Kelas II A Madrasah Ibtidaiyah Raudhatul Ulum Sakatiga Indralaya Ogan Ilir

Komputri Apria Santi

\begin{tabular}{|l|l|l|l|l|}
\hline \multirow{2}{*}{ Jumlah } & & & $\sum \mathrm{D}=$ & $\sum \mathrm{D}^{2}=$ \\
& & -510 & 213.000 \\
\hline
\end{tabular}

Dengan diperolehnya $\sum \mathrm{D}$ dan $\sum \mathrm{D}^{2}$ itu, maka dapat kita ketahui besarnya Deviasi Standar Perbedaan Skor antara Variabel X dan Variabel Y (dalam hal ini SDD) :

$$
\begin{aligned}
\mathrm{SD}_{\mathrm{D}} & =\sqrt{\frac{\sum \mathrm{D}^{2}}{\mathrm{~N}}-\left(\frac{\sum \mathrm{D}}{\mathrm{N}}\right)^{2}}=\sqrt{\frac{21.300}{22}-\left(\frac{-510}{22}\right)^{2}} \\
& =\sqrt{968,18-(23,18)^{2}} \\
& =\sqrt{968,18-537,31} \\
& =\sqrt{430,87} \\
& =20,75
\end{aligned}
$$

Dengan diperolehnya SDD sebesar 20,75 itu, lebih lanjut dapat kita perhitungkan Standard Error dari Mean Perbedaan Skor antara Variabel X dan Variabel Y :

$$
\begin{aligned}
\text { SEMD } & =\frac{\mathrm{SD}_{\mathrm{D}}}{\sqrt{\mathrm{N}-1}}=\frac{20,75}{\sqrt{22-1}}=\frac{20,75}{\sqrt{21}} \\
& =\frac{20,75}{4,58}=4,53
\end{aligned}
$$

Langkah berikutnya adalah mencari harga to dengan menggunakan rumus :

$t_{0}=\frac{\mathrm{M}_{\mathrm{D}}}{\mathrm{SE}_{\mathrm{MD}}}$

MD telah kita ketahui yaitu $-23,18$; sedangkan $S E M D=4,53$; jadi :

$\mathrm{to}_{\mathrm{o}}=\frac{-23,18}{4,53}=-5,11^{3}$

Keterangan :

SDD = Deviasi Standar Perbedaan Skor

SEMD = Standard Error dari Mean Perbedaan Skor Antara Variabel X dan Variabel Y

$\mathrm{N} \quad=$ Number of Cases

to $\quad=$ Tes observasi

$\mathrm{t}_{\mathrm{t}} \quad=$ Tes Tabel

" $\mathrm{t}$ " = Tes Perhitungan

MD = Mean of DifferenceNilai Rata-rata Hitung dari Beda / Selisih antara Skor Variabel I dan Skor Variabel II

Langkah berikutnya, kita berikan interpretasi terhadap $t_{0}$, dengan terlebih dahulu memperhitungkan df atau db-nya: $\mathrm{df}$ atau $\mathrm{db}=\mathrm{N}-1=22-1=21$. Dengan $\mathrm{df}$ sebesar 21 kita berkonsultasi pada tabel nilai " $\mathrm{t}$ ", baik pada taraf signifikansi $5 \%$ maupun pada taraf signifikansi $1 \%$.

Ternyata dengan $\mathrm{df}$ sebesar 22 itu diperoleh harga kritik $\mathrm{t}$ atau tabel tabel signifikansi 5\% sebesar 2,08; sedangkan pada taraf signifikansi $1 \% \mathrm{t}$, diperoleh sebesar 2,83 .

${ }^{3}$ Sekali lagi diingatkan bahwa tanda - (minus) di sini bukanlah tanda aljabar; karena itu dengan $t_{o}$ sebesar $-5,11$ itu dapat kita baca: ada selisih derajat perbedaan sebesar 5,11 
Dengan membandingkan besarnya " $\mathrm{t}$ " yang kita peroleh dalam perhitungan $\left.\left(t_{0}=5,11\right)\right)$ dan besarnya " $t$ " yang tercantum pada Tabel Nilai $t\left(t_{t . t .5} . \%=2,09\right.$ dan tt.ta. $1 \%=2,83$ ) maka dapat kita ketahui bahwa to adalah lebih besar daripada $t_{t}$ yaitu $: 2,09<5,11>2,83$

Karena to lebih besar daripada $t_{t}$ maka Hipotesis Nihil yang diajukan dimuka ditolak; ini berarti bahwa adanya perbedaan nilai siswa antara sebelum dan sesudah diterapkannya Media Gambar merupakan perbedaan yang berarti atau perbedaan yang meyakinkan (signifikan).

Simpulan yang dapat kita tarik disini ialah, berdasarkan hasil uji coba tersebut diatas, secara meyakinkan dapat dikatakan bahwa Penerapan Media Gambar Untuk Meningkatkan Hasil Belajar Kosa Kata Bahasa Arab (mufrodat)Pada Siswa Kelas II A MI Raudhatul Ulum, telah menunjukkan efektivitasnya yang nyata.

\section{Simpulan}

1. Berdasarkan data yang diperoleh mengenai penerapan media gambar mufrodat bahasa Arab di kelas II A Madrasah Ibtidaiyah Raudhatul Ulum Sakatiga dalam kategori sebagai berikut: 75,75\% dalam kategori baik, 21,97\% dalam kategori kurang baik, dan 2,27\% dalam kategori kurang baik.

2. Berdasarkan hasil penggunaan Tes " $\mathrm{t}$ ", secara meyakinkan dapat dikatakan bahwa Penerapan Media Gambar Untuk Meningkatkan Hasil Belajar Kosa Kata Bahasa Arab (mufrodat)Pada Siswa Kelas II A MI Raudhatul Ulum, telah menunjukkan efektivitasnya yang nyata. Hal ini dapat di buktikan karena to lebih besar daripada ttyaitu:2,09<5,11>2,83. 
Penerapan Media Gambar Untuk Meningkatkan Hasil Belajar Kosakata Bahasa Arab (Mufrodat) Pada Siswa Kelas II A Madrasah Ibtidaiyah Raudhatul Ulum Sakatiga Indralaya Ogan Ilir

Komputri Apria Santi

\section{DAFTAR PUSTAKA}

Arikunto, Suharsimi. 2010. Manajemen Penelitian. Jakarta: Rineka Cipta. 2010. Prosedur Penelitian: Suatu Pendekatan praktsis. Jakarta: Rineka Cipta.

Asra,Sumiati.2008. Metode pembelajaran. Bandung: Wacana Prima.

Aswan Zain, Syaiful Bahri Djamarah. 2002. Strategi Belajar Mengajar. Jakarta: Rineka Cipta.

Azhar, Arsyad.2008. Media Pembelajaran. Jakarta: PT Raja Grafindo Persada. . 2010.Media pembelajaran. Jakarta: Rajawali Pers, Cet Ke-13.

Daryato. 2010.Belajar dan Mengajar. Bandung: CV.Yrama Widya.

Djamarah, Syaiful Bakhri. 2006.Strategi Belajar Mengajar. Jakarta, PT. Rineka Cipta. .2002. Strategi BelajarMengajar, Jakarta: Rineka Cipta, Cet

Ke-2.

Hadi, Sutrisno.1980.Metodologi Reseach. Yogyakarta: Fakultas Psikologi UGM. . 1985.Metode Penelitian.Jakarta: Ghalia Indonesia, Cet. Ke-1.

Hermawan, Acep. 2011.Metodologi Pembelajaran Bahasa Arab. Bandung: PT Remaja Rosdakarya.

Kamus Besar Bahasa Indonesia. 2009. Jakarta: Pustaka Phoenix, Cet Ke-IV.

Kosasih A, Rubertus Angkowo.Optimalisasi Media Pembelajaran.Jakarta: PT

Moleong, Lexy J.2005. Metodologi Penelitian Kualitatif.Bandung: Remaja Rosda Karya.

Mu'in, Abdul. 2004.Analisis Kontrastif Bahasa Arab \& Bahasa Indonesia.Jakarta: PT. Pustaka Al-Husna Baru.

Novia, Windy.Kamus Lengkap Bahasa Indonesia. Surabaya: Kashiko press

Saebani, Beni Ahmad. 2008.Metode Penelitian. Bandung: Pustaka Setia.

Sadiman,Arief S. dkk. 2009.Media Pendidikan. Jakarta: Rajawali Pers.

Sudijono, Anas. 2010.Pengantar Statistik Pendidikan, Jakarta: Raja Grafindo Persada

Sugiono. 2009.Statistika Untuk Penelitian. Bandung, Alfabeta.

Syah, Muhibbin. 2006.Psikologi Belajar. Jakarta: Raja Grafindo Persada.

Wahid Abdul,Mustaqim. 2003.Psikologi Pendidikan.Jakarta: Rineka Cipta.

Widoyoko, Eko Putra. 2010.Evaluasi Program Pembelajaran. Yogyakarta: Pustaka Pelajar. 